\title{
The New Zombie Apocalypse and Social Crisis in South Korean Cinema (translation into Russian) ${ }^{1}$
}

\author{
Sung-Ae Lee \\ Macquarie University. Sydney, Australia. Email: sung-ae.lee[at]mq.edu.au \\ Abstract
}

The popular culture version of the zombie, developed over the latter half of the twentieth century, made only sporadic appearances in South Korean film, which may in part be attributed to the restrictions on the distribution of American and Japanese films before 1988. Thus the first zombie film Monstrous Corpse (Goeshi 1980, directed by Gang Beom-Gu), was a loose remake of the SpanishItalian Non si deve profanare il sonno dei morti (1974). Monstrous Corpse was largely forgotten until given a screening by KBS in 2011. Zombies don't appear again for a quarter of a century. This article examines four zombie films released between 2012 and 2018: "Ambulance", the fourth film in Horror Stories (2012), a popular horror portmanteau film; Train to Busan (2016) (directed by Yeon Sang-Ho), the first South Korean blockbuster film in the "zombie apocalypse" sub-genre; Seoul Station (2016), an animation prequel to Train to Busan (also directed by Yeon Sang-Ho); and Rampant (2018, directed by Kim Seong-Hun ), a costume drama set in Korea's Joseon era. Based on a cognitive studies approach, this article examines two conceptual metaphors which underlie these films: the very common metaphor, LIFE IS A JOURNEY, and the endemically Korean metaphor THE NATION IS A FAMILY.

\section{Keywords}

Zombie; Social Crisis; South Korean Cinema

\section{(c) (i)}

This work is licensed under a Creative Commons «Attribution» 4.0 International License

1 We are grateful to the author and publishers for permission to translate and publish the article (Lee Sung-Ae (2019), The New Zombie Apocalypse and Social Crisis in South Korean Cinema. Coolabah, 27, 2019, https://doi.org/10.1344/co201927150-166 


\title{
Новый зомби-апокалипсис и социальный кризис в южнокорейском кино (перевод на русский) ${ }^{1}$
}

\author{
Ли Сон Э \\ Университет Маккуори. Сидней, Австралия. Email: sung-ae.lee[at]mq.edu.au

\section{Аннотация}

Образ зомби в популярной культуре, сложившийся во второй половине XX века, лишь спорадически появлялся в южнокорейском кино, что отчасти можно объяснить ограничениями на прокат американских и японских фильмов до 1988 года. Так, первый фильм о зомби «Чудовищный труп» (“Goeshi”, 1980, режиссер Кан Бом Гу) был вольным ремейком испано-итальянского «Пускай мёртвые лежат в могилах» (“Non si deve profanare il sonno dei morti”, 1974). Фильм «Чудовищный труп» был практически забыт, пока в 2011 году его не показали на канале KBS. На протяжении четверти века зомби не появлялись в кино. В этой статье анализируются четыре фильма о зомби, выпущенные в период с 2012 по 2018 год: «Скорая помощь», четвертый фильм из киноальманаха «Истории ужасов» (“Horror Stories”, 2012); «Поезд в Пусан» (2016) (режиссер Ён Сан Хо), первый южнокорейский блокбастер в поджанре «зомби-апокалипсис»; «Станция Сеул» (2016), анимационный приквел к «Поезду в Пусан» (также режиссер Ён Сан Хо); и «Ярость» (“Rampant”, 2018, режиссер Ким Сон Хун), костюмированная драма, действие которой происходит в Корее в эпоху Чосон. В статье с опорой на когнитивный подход рассматриваются две концептуальные метафоры, лежащие в основе этих фильмов: очень распространенная метафора «Жизнь - это путешествие» и исконно корейская метафора «Нация - это семья».

\section{Ключевые слова}

зомби; социальный кризис; южнокорейское кино

Это произведение доступно по лицензии Creative Commons «Attribution» («Атрибуция») 4.0 Всемирная

1 Редакция благодарит автора и издателей за разрешение на перевод и публикацию статьи Lee Sung-Ae (2019), The New Zombie Apocalypse and Social Crisis in South Korean Cinema. Coolabah, 27, 2019, https://doi.org/10.1344/co201927150-166 


\section{Введение}

Трагические для Кореи события в течение большей части XX века (японская колонизация, Корейская война и почти 40 лет военной диктатуры) оставили заметные психологические шрамы в национальном сознании, и недавнее появление жанра зомби-повествования стало еще одним средством для выражения социального воздействия этой истории. Порожденная глобализацией версия зомби в популярной культуре, которая сформировалась во второй половине XX века, лишь изредка появлялась в южнокорейском кино до наступления XXI века, что отчасти можно объяснить ограничениями на прокат американских и японских фильмов до 1988 года (год проведения Олимпийских игр в Сеуле). Так, первый корейский фильм о зомби, «Чудо-

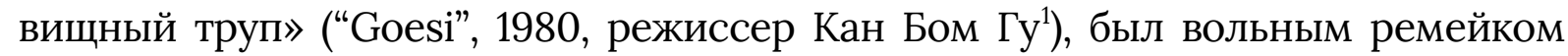
испано-итальянского «Пускай мертвые лежат в могилах» ("Non si deve profanare il sonno dei morti", 1974). Однако этот фильм оказался быстро забыт, и еще четверть века зомби не появлялись на экранах. Интерес к зомби пробудился лишь в начале XXI века после выхода двух фильмов о зомби: шаблонного «Темного леса» (“Dark Forest”, 2006) режиссера Ким Чон Мина и получившего хорошие отзывы «Соседского зомби» (“The Neighbour Zombie", 2009), малобюджетной антологии, над которой работали четыре режиссера-новичка. Состоящий из шести историй, объединенных темой вспышки зомби-вируса в Сеуле, «Соседский зомби» исследует несколько проблем, которые повторяются в последующих фильмах о зомби, особенно вопросы человеческого сознания и склонности власть имущих пренебрегать бедственным положением обычных или маргинальных людей и использовать трагедию в своих интересах. Так, в четвертой части (режиссер Рю Хун) ученый, работающий на корпорацию, из которой вырвался вирус, создает вакцину для его лечения, однако он вынужден бежать, когда корпорация пытается убить его, чтобы единолично владеть вакциной. Пятая часть (режиссер Чан Юн Чжон) посвящена посттравматическому стрессу, вызванному воспоминаниями об ужасах, совершенных теми зомби, которых вакцина вернула к человеческой жизни, и теми гражданами, которые совершали отвратительные поступки, сохраняя человеческий облик. Однако зомби - это не просто метафора травмы и испытанных унижений. Говоря о значимости фильмов о зомби в американском кино, Дэниел В. Дрезнер утверждает, что живые мертвецы являются метафорой различных тревог в американской телесной политике, подверженной асимметричным угрозам и экономической неопределенности (2014, р. 825-826).

Аналогичным образом Линни Блейк в формулировке, которая также перекликается с современными корейскими реалиями, предполагает, что «зомби-апокалипсис дал аудитории возможность взглянуть и осмыслить

1 Имена следуют в обычном корейском порядке, а именно: за фамилией располагается имя. Во всем англоязычном тексте применяется новая романизация корейского языка (прим. автора). 
современную делинквентность политического тела, зараженного неолиберализмом. Короче говоря, зомби - это монстр, которого выбирает поколение, уставшее от десятилетнего содействия правительства антидемократическим импульсам неолиберального корпоративизма» (2015, р. 28). Сходная тенденция в Южной Корее вызвана последствиями попытки навязать неолиберальную экономику Международным валютным фондом в 1997 году, господством нескольких семейных компаний и эндемической коррупцией в правовой и политической системах: жанр зомби-апокалипсиса используется в качестве метафоры глобального кризиса, беспорядка и страха. Вмешательство МВФ очередной пример угрозы вторжения чужаков, которая нависала призраком и была реальностью - на Корейском полуострове на протяжении веков, она открыто прослеживается в историческом фильме «Ярость» ("Rampant", 2018), где зомби-вирус распространяется на корабле, капитаном которого является голландскоговорящий представитель Запада, чей бизнес заключается в продаже оружия группировке, планирующей свержение королевской семьи. Общественные структуры и институты, включая правительство и вооруженные силы, не только не способны остановить хаос, возникающий во время зомбиэпидемии, но и могут стать ее причиной. Приписывание источника вируса биотехнологической или фармацевтической компании, как в фильмах «Соседский зомби» или «Поезд на Пусан» (2016), обличает безответственность таких компаний в их стремлении к увеличению прибыли и монополии на дорогостоящие продукты, а также выражает скептицизм в отношении масштабов государственного попустительства в пользу этих компаний и против интересов народа.

\section{Зомби и символическая репрезентация}

В этой статье рассматриваются несколько фильмов о зомби, снятых в Южной Корее в период с 2012 по 2018 год: «Скорая помощь», четвертая часть популярного киноальманаха «Истории ужасов» (2012); «Поезд в Пусан» (2016) (режиссер Ён Сан Хо), первый южнокорейский блокбастер в поджанре «зомбиапокалипсис»; «Станция "Сеул"» (Seoul Station, 2016), анимационный приквел к фильму к «Поезду в Пусан» (Train to Busan, 2016, также режиссер Ён Сан Хо); «Ярость» (Rampant, 2018, режиссер Ким Сон Хун), драма, действие которой происходит в Корее в эпоху Чосон (жанр, известный как сагык). Некоторые примеры почерпнуты из «Королевства» (2019), телевизионного драматического сериала, который в момент написания данной статьи ещё продолжает выпускаться. С опорой на когнитивный подход, мы рассматриваем две концептуальные метафоры, лежащие в основе этих произведений: весьма распространенную метафору «Жизнь - это путешествие», и типично корейскую метафору «Нация - это семья». Эти метафоры проявляются в виде расхожих сценариев или фабул (путешествие, например, имеет цель, начало, ряд столкновений и конец), но, как утверждал Дэвид С. Миалл в своей значимой статье 
«За пределами заданной схемы», простые модели не могут объяснить разворачивающиеся и меняющиеся значения сложных повествований и должны быть изменены или адаптированы. Процесс понимания также направляется аффектами. Миалл утверждает, что аффект «позволяет применить эмпирические и оценочные аспекты Я-концепции читателя к процессу понимания; [он] позволяет проводить межпредметную категоризацию элементов текста»; и он предварительно структурирует понимание смысла текста аудиторией (р. 56).

Функциям аффекта в фильмах ужасов уделяется значительное внимание со стороны различных исследователей (например, Bartsch et al, 2010; Hoglund, 2013; Winter, 2014; Benson-Allott, 2015). В основе этих дискуссий лежит работа Сильвана Томкинса (1963), который утверждал, что аффекты придают глубину человеческому существованию через самосознание и межсубъектные отношения. Благодаря тому, что аффективный опыт имеет тенденцию к накоплению, мы можем разрабатывать и использовать комплексные аффективные стратегии, чтобы взаимодействовать с нашим социальным миром. Фильмы о зомби, однако, основаны на возможном разрушении этого социального мира, и как аффект, «ужас возникает как связь между субъектами и объектами, угрожая воспринимающему его или ее ничтожностью и эфемерностью как объекта» (Benson-Allott, p. 268). Поскольку в центре фильмов о зомби находятся тела, которые трансформируются и становятся монструозными - некогда человеческие, но теперь нет, - они порождают страх и вину у персонажей, которые, пусть и временно, избежали зомбификации. С другой стороны, часть персонажей превращается в альтруистов, преодолевая эгоизм. Эта трансформация особенно очевидна в фильме «Поезд в Пусан».

Как нежить зомби символически представляют последствия утраты самости (Wonser and Boyns, p.632) и последующего исключения из любой актуализации «Жизни - путешествия», ведь между моментом трансформации и любым показанным разрушением у зомби отсутствует сознание, агентность, социальная жизнь или обдуманные действия. У зомби есть только желание к передвижению со стаей зомби и к убийству. Аналогично метафора «Нация это семья» не может быть применима к зомби, который уже не является членом ни нации, ни семьи. Ни один из фильмов, рассматриваемых в данной статье, не выказывает интереса к конкретной личности зомби или к жизни персонажа после превращения в зомби. Он или она просто исчезают в обезличенной орде, даже те персонажи «Поезда в Пусан» или «Ярости», которые вовлекали аудиторию в сильное аффективное участие. Здесь полезным аргументом является применение Митчеллом Трэвисом концепции Агамбена о «голой жизни» к человеку, который не обязательно рассматривается как имеющий социально или морально значимую жизнь и, таким образом, находится вне границ социального порядка и юридических структур (pp. 795-796). Соответственно, то, как поступают с таким человеком, не имеет этических последствий (Wonser and Boyns, p. 635). Однако, в «Станции Сеул» и «Ярости» правители не устанавливают моральных различий между людьми и зомби и, 
рассматривая нашествие как восстание, убивают без разбора. Стирание личности зараженных персонажей, таким образом, соответствует процессам отчуждения, которые охватывают не только нежить, но и низшие классы, людей, угрожающих безопасности, террористов, инопланетян или женщин. В «Ярости» заражение начинается с иностранного торгового судна, а в «восстании» в «Станции Сеул» виноваты «коммунисты», то есть Северная Корея.

\section{Просоциальное и эгоистическое поведение в фильмах о зомби}

Как утверждает Бишоп (Bishop, 2015, р.14), новые тенденции в фильмах о зомби в XXI веке рождены «коллективными страхами и тревогами мира по поводу террористических атак и глобальной пандемии. Поскольку зомби выглядят как наши бывшие друзья и близкие, они воплощают собой террориста в штатском или экстремиста с промытыми мозгами». В Южной Корее такие тревоги выражены в виде коллективных страхов по поводу северокорейского терроризма и глобальных пандемий (атипичная пневмония, птичий грипп, коровье бешенство [BSE]), а также культурных проблем, связанных с иммиграцией и политикой идентичности. Наконец, что важно, основным тематическим элементом южнокорейского зомби-фильма является контраст между просоциальным и эгоистичным поведением и лежащий в его основе классический контраст между эгоизмом и альтруизмом / эмпатией. Как постоянно повторяющаяся тема, контраст между просоциальным и эгоистическим поведением прослеживается в кино, телевизионной драме, по крайней мере, с конца 1980-х годов. В последнее время экстремальным воплощением эгоистического поведения стали зомби, поскольку, хотя они и лишены эго, их единственное желание нападать на людей отражает стремление к выживанию, катастрофически усиливающееся у эгоистичных людей во время кризиса. Среди персонажей фильмов о зомби всегда есть один или два человека, которые настолько эгоистичны, что не могут осознать, что их выживание, ради которого они готовы пожертвовать всей страной, зависит от просоциальных действий. В своем обзоре мотивов и условностей западных фильмов о зомби Роберт Вонсер и Дэвид Бойнс (2016) отмечают, что те, кто выживает в зомби-апокалипсисе, делают это благодаря созданию поддерживающих и защитных социальных сетей; напротив, «крайне редко можно встретить одиночку, который успешно выживает без социальной поддержки; большинство выживших в зомби-апокалипсисе вынуждены сотрудничать» (р. 642-643). Корейское кино про зомби воспроизвело эту идею конвенции и объединило ее с проблемой противостояния просоциального и эгоистичного поведения.

Как уже упоминалось выше, зомби могут символизировать самые разнообразные явления, но, в то же время, их значение может оставаться неясным, как, например, в фильме «Скорая помощь» - первой истории о зомби, появив- 
шейся в кино после «Соседского зомби». Хотя движение машины скорой помощи через один район в другой показывает, что в основе сюжета лежит зона боевых действий в условиях вторжения в Сеул, в центре внимания этого короткометражного фильма - неспособность небольшой группы людей поддерживать необходимый для выживания уровень просоциального поведения. Фильм длится всего двадцать четыре минуты, и действие происходит в основном в ограниченном пространстве движущейся машины скорой помощи, поэтому зомби появляются, лишь преследуя или нападая на машину. Подобное изображение зомби в качестве катализатора или врага, вторичного по отношению к персонажам-людям, является нормой для южнокорейского кино. Действие, разыгрывающееся в машине, связано с метафорами «Жизнь это путешествие» и «Нация - это семья». Скорую помощь, движущуюся по городу, кишащему зомби, останавливает женщина, пытающаяся спасти раненую дочь, до последних секунд повествования остающуюся без сознания. Экипаж машины состоит из водителя, женщины-медсестры и военного санитара. Между санитаром, медсестрой и матерью возникает конфликт из-за непонятной раны на руке ребенка: мать уверяет, что ее причиной является дорожно-транспортное происшествие, но санитар считает, что это укус зомби, и настаивает на том, чтобы ребенка выкинули из машины. Жизнь каждого в этом микрокосме зависит от урегулирования их конфликтующих желаний: мать ставит семью превыше всего и в итоге убивает других взрослых; санитар одержим идеей личного выживания; а медсестра упорно придерживается профессиональных и альтруистических взглядов. Мать, санитар и медсестра отражают модели, которые встречаются во всех рассматриваемых здесь текстах о зомби.

Например, в аналогичном сюжете, показанном в третьем и четвертом эпизодах телевизионного драматического сериала «Королевство», мать-аристократка отказывается сжечь зомбированное тело своего «драгоценного сына» и переправляет его на корабль с бегущими городскими чиновниками, элитой и военачальниками. При этом мать изображена неприятной, а чиновники и аристократы, сбежавшие от ответственности и не озаботившиеся судьбой простого народа, вызывают презрение своими заявлениями, «благородные люди - опора страны» и должны выжить (Эп.3, 47:50). Самоидентификация аудитории с покинутым народом предопределяет исход. Зритель не только ожидает и надеется на появление зомби на корабле, но и соглашается с гибелью персонажей и испытывает от этого удовлетворение. Повторяющаяся идея самосохранения контрастирует с альтруизмом в замкнутом пространстве машины скорой помощи и поезда в фильме «Поезд в Пусан». В последнем, один из самых впечатляющих моментов происходит ближе к концу двадцатиминутного отрезка (00:54 и далее), когда после неудачной попытки найти охрану на станции Тэджон выжившие пассажиры разделяются на три группы. Сок У, Сан Хва и Ён Гук объединяются, чтобы прорваться через зомби в четырех вагонах поезда и спасти четырех пассажиров, включая дочь 
Сок У (Су Ан) и жену Сан Хва (Сон Гён). Сделав это, они проходят еще через один вагон, где выясняется, что остальные пассажиры во главе с эгоистичным бизнесменом Ён Соком забаррикадировали смежную дверь и не пускают их. В очень трогательной сцене матерящийся рабочий Сан Хва вверяет свою жену заботам Сок У и жертвует собой, чтобы дать остальным шанс выжить ${ }^{2}$ В отличие от альтруистического поступка Сан Хва, Ён Сок демонстрирует готовность пожертвовать всеми остальными в поезде ради собственного спасения. Когда группа Сок У все же врывается в вагон, он заявляет, что они заражены, остальные пассажиры поддерживают его требование перевести новоприбывших в тамбур. В двух последующих сценах Ён Сок выталкивает других людей к зомби, чтобы спастись самому (01:31:15, проводник поезда; 01:33:31, школьница Чин Хи). Основные контрасты между эгоизмом и альтруизмом в этих сценах (и других) еще ярче демонстрируют, как аффект предварительно структурирует понимание и реакцию: проще говоря, зритель почувствует, что Сон Гён должна выжить как достойный результат альтруизма Сан Хва, и что Ён Сок достоин презрения и не заслуживает спасения.

Три социальные группы на спасающемся судне в «Королевстве» - аристократы, чиновники и высшие военные - функционируют как аллюзия на социально-политическую структуру современной Южной Кореи. Южнокорейские исторические драмы всегда связаны с настоящим и легко наводят на мысль о сходстве между, например, аристократами эпохи Чосон, владеющими и потребляющими большую часть ресурсов страны, и наследующими семейные компании современными чеболями, которые составляют $1 \%$ населения и контролируют 60 \% богатства страны. Аналогично, социальные модели, представленные в «Скорой помощи», могут рассматриваться как отражение более широких социальных явлений, таких как самодостаточная семья, те, кто обладает политической и судебной властью, обычный рабочий (водитель) и профессионалы. Как микрокосм общества, скорая помощь должна быть средством (буквально и метафорически), поддерживающим человека на жизненном пути. Вместо этого она воплощает внушаемые персонажам (и зрителям) беспомощность и паранойю, порожденные конфликтом между самосохранением и моральным поведением из-за социального раскола, вызванного вспышкой зомби. Завязка «Скорой помощи» наводит на мысль, что эта история - мрачная аллегория социальной солидарности. Убив санитара, медсестру и водителя (укушенного во время нападения зомби), мать выводит машину в «безопасную» зону, где та разбивается. Едва пришедшую в себя «уже не зомби» дочь кусает зомби-мать, пережившая превращение и утратившая любые воспоминания из прежней жизни вместе со стремлением безжалостно ее защищать. В результате в путешествии никто не выжил, семья распалась, а зомби проникли в безопасную зону, знаменуя и крах нации.

1 Аффективная привлекательность этого персонажа подтверждается национальной и международной популярностью актера Ма Дон Сока после показа фильма. «Поезд в Пусан везет Дона Ли [Ма Дон Сока] в Голливуд». http://koreatimes.co.kr/www/news/nation/2016/09/398_214970.html 


\section{Социальные беспорядки как причина зомби-апокалипсиса}

«Скорая помощь» и ужасающий анимационный приквел к фильму «Поезд в Пусан» «Станция Сеул» - это зомби-апокалипсисы, в которых нет выживших. Только два пассажира в фильме «Поезд в Пусан» в конце пути остаются людьми - беременная женщина (Сон Гён) и маленькая девочка (Су Ан), что является явной аллюзией на повествования об апокалиптических катастрофах, таких как легендарная книга Джорджа Р. Стюарта «Земля обитаема» (Earth Abides,1949) и роман Роберта О'Брайена «Z - значит Захария» (1974), в котором небольшая группа планирует заново заселить разрушенный мир. В «Станции Сеул» вспышка эпидемии связана с некомпетентностью правительства и широко распространившимися социальными проблемами. Научная ошибка, причиной которой является экономический авантюризм, разрушает природный порядок; политики используют СМИ, чтобы скрыть это; обществом движут корыстные интересы и вера в иерархию и власть; в результате альтруистическое меньшинство может спасти очень мало граждан. Предположение о том, что зомби-апокалипсис в Южной Корее является отражением социального кризиса, наиболее сильно звучит в первые 18 минут фильма «Станция Сеул», во время первого нападения зомби. На фоне тускло освещенных улиц, начало фильма показывает дистопию, населенную безработными, бездомными, алкоголиками и проститутками. В первой сцене появляется растрепанный пожилой мужчина, истекающий кровью из-за раны на шее. Двое молодых людей, мимо которых он проходит, обсуждают необходимость создания всеобщей системы социальной поддержки, решают помочь ему, но успев понять, что он бездомный и учуяв его запах, передумывают. Другие прохожие не проявляют никакого участия. Попытку помочь предпринимает друг, еще один бездомный, но он оказывается бессилен перед безразличием чиновников и враждебностью общества. Эта линия продолжается на протяжении всего начала фильма до поворотного момента, когда мужчина зомбируется (18:46).

Другая сюжетная линия, завязывающаяся в начале фильма, связана с беглой девочкой-подростком Хё Сон. «Жизнь - это путешествие» и «Нация это семья» снова сходятся в путешествии Хё Сон. Она живет со своим парнемэгоистом в неприглядном многоквартирном доме, у нее нет денег, и она не может заплатить за квартиру. Проснувшись и обнаружив, что ее парень куда-то ушел, она ищет его в интернет-кафе, где он только что разместил объявление с предложением ее сексуальных услуг. Они ссорятся, и девочка бродит по темному городу, прибывая на станцию Сеул после 12:30, когда появляется первая толпа зомби (25:15). На протяжении всего фильма она спасается от зомби, заполонивших город. Ее также ищет Сок Гю, человек, который выдает себя за ее отца, а на самом деле является жестоким сутенером, от которого она сбежала в предыстории. Смешение образов отца и сутенера, понятий защиты и эксплуатации перекликается с повторяющимися жалобами представителей 
низших слоев на то, что общество их использовало и выбросило («Этой стране на нас наплевать» [01:08:57]). Все ставит под сомнение метафору «Нация - это семья». Визуально идея подкрепляется повторяющимися рекламными щитами, на которых говорится о доступности новых роскошных квартир, что выглядит как издевательство над бездомными, спящими под этими щитами на сеульской станции. Аффективная реакция зрителя на такой прием заранее предопределяет понимание текста. Появление на экране полиции и военных только усиливает ощущение пренебрежения к простым гражданам, поскольку их отождествляют с зомби и обвиняют в организации восстания, что, в свою очередь, становится поводом для объявления военного положения и нападения на граждан с применением слезоточивого газа, водометов и пуль (01:00). Эти сцены намекают на многочисленные проявления жестокости полиции или военных в реалистических фильмах, изображающих подавление демократического движения в Кванджу в 1980 году. Среди классических фильмов «Мятные леденцы» (1999), «Старый сад» (2006) и «18 мая» (2007), но эта тема представляет собой целый кинематографический поджанр, примером которого недавно стал фильм «Таксист» (2017). Интертекстуальный эффект, открыто проявляющийся в предпоследней сцене фильма, где изображены зомби, которых расстреливают военные, ставит под сомнение любое предположение о том, что нация - это семья.

Зрители легко отличают неинфицированных от инфицированных, но «Станция Сеул» - это эмоционально сдержанный фильм, только персонажи небольших ролей вызывают сочувствие зрителей: помогающий Хе Сон бездомный средних лет, которого застрелили, когда он протестовал против жестокого обращения с обычными людьми; и молодой человек, воплощающий идею альтруизма, спасая Хе Сон ценой собственной жизни (01:13:50). Хё Сон могла бы вызвать некоторое сочувствие как слабая женщина-жертва, лишенная какой-либо независимости, но ей не приписывают никакой внутренней силы, и она не проявляет особой заботы о других людях. В конце фильма после того, как она укрылась в одной из рекламируемых роскошных квартир, ее ловит Сок Гю, избивает ногами до полубессознательного состояния и собирается изнасиловать в дорого обставленной спальне. Из ее глаза течет слеза. Возможно, из-за осознания той ловушки насилия, в которую она угодила. Вскоре она умирает и превращается в зомби, но зрители не испытывают особого удовлетворения от сцены уничтожения сутенера и преследователя у нее есть сила зомби, но нет ни памяти, ни сознания, а значит теперь еще меньшей независимости, чем в начале фильма. Воздействие здесь формируется не сопереживанием Хё Сон и не удовлетворением естественной справедливостью по отношению к Сок Гю, а значимостью обстановки, подтверждающей социальную предвзятость, которая довлеет над населением. Зрителям не виден непосредственно конец Сок Гю, а лишь тень Хё Сон, когда она подходит к тому месту, где бросила его на пол. Тень скользит по дорогому 
туалетному столику, а свет ярко падает на настенную табличку с подробным описанием и стоимостью предмета (см. рис. 1).

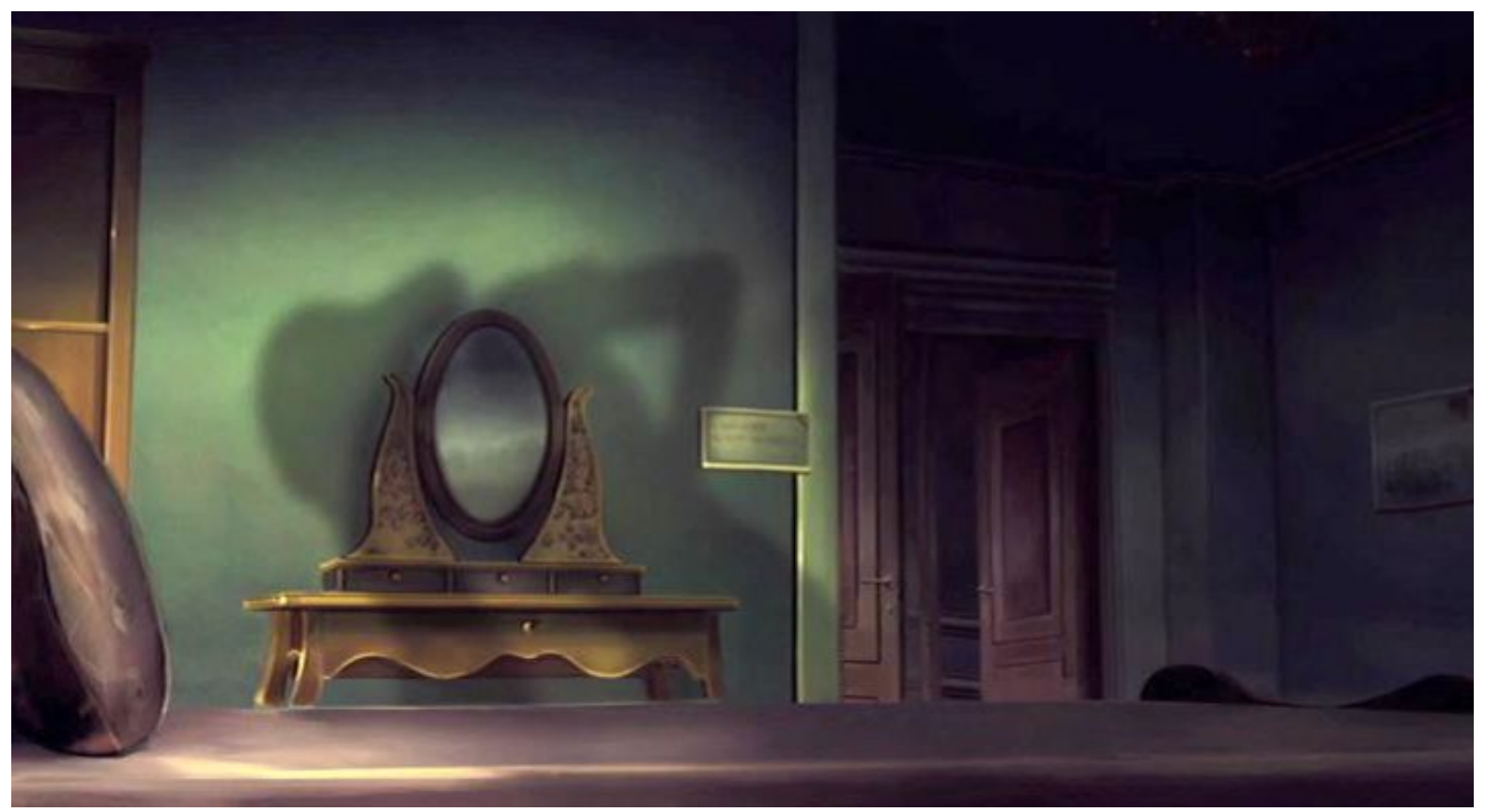

Рисунок 1. Хё Сон зомбирует Сок Гю

Figure 1. Hye-Seon Zombifies Seok-Gyu

Поскольку зомби являются символическим представлением последствий потери самости, кажется очевидным, что отсутствие личности у Хё Сон-зомби является лишь продолжением отсутствия личности у молодой женщины в андроцентричном обществе, которое относится к ней как к бесправному имуществу. Возможно, что еще одной причиной недостатка сопереживания аудитории по отношению к Хё Сон является то, что она признает свою «голую жизнь».

\section{Аффект и развязка в фильме «Поезд в Пусан»}

Аффект играет более существенную роль в фильме «Поезд в Пусан», особенно в его очень сильной концовке. С самого начала фильма зритель находится между опасениями и надеждами, потому что, как и в «Стании Сеул», режиссер Ён Сан Хо открывает фильм образами дистопического общества: фермеры страдают от экономической неопределенности и страха перед новой пандемией; семьи неблагополучны, примером чему служит распавшийся брак Сок У и его плохие отношения с дочерью Су Ан; исследовательский центр вызвал экологический кризис, который власти игнорируют как незначительную проблему; финансовые учреждения жадны, оппортунистичны и 
не обращают внимания на экономический ущерб, который они наносят в своем стремлении к прибыли.

Мощный образ создает сцена, завершающая дотитровый фрагмент фильма: фермер ведет свой грузовик через контрольно-пропускной пункт, контролируемый человеком в одежде химической защиты, и знает, что ему солгали о причине проверки. Затем его грузовик сбивает и убивает оленя на дороге, но когда он отъезжает, мертвое животное с трудом поднимается на ноги, и последний крупный план, когда оно смотрит в камеру, показывает окровавленную шею и остекленевшие глаза зомби. Кадр явственно свидетельствует о том, что это фильм о зомби, но также и о том, что зомби здесь олицетворяют масштабный социальный и экологический кризис. Навеяв тревогу, фильм переходит к титрам.

Вводные виньетки о научной и экономической безответственности, эгоизме в семейной жизни и экологическом кризисе также определяют основной тематический элемент фильма - контраст между эгоистичным и просоциальным поведением и лежащий в его основе классический контраст между эгоизмом и альтруизмом. Эти контрасты заметны детально в поведении Сок У и Су Ан, но также проявляются в других персонажах. Персонажи фильмов о зомби могут быть неизменными, как и сами зомби в их бездумном стремлении нападать на людей, но они не определяются, как зомби, одной характеристикой. Сложность персонажа может проявиться по мере развития фильма, как в случае с Сан Хва: он не развивается в течение короткого путешествия, но обнаруживает глубины уважения, сострадания и мужества в своей реакции на экстремальную ситуацию, когда большинство пассажиров поезда превращаются в зомби. В отличие от него, Сок У - персонаж, который развивается, под воздействием событий превращаясь из эгоцентричного индивидуалиста в человека, способного мыслить альтруистично. Его первоначальное поведение подчеркивает его эгоцентризм: например, когда Су Ан уступает свое место пожилой женщине Чон Гиль, Сок У делает ей замечание: «Ты не должна была этого делать... в такое время нужно следить только за собой» (34:42). Су Ан оправдывает свой поступок тем, что у ее бабушки были больные колени - то есть ее физическое объяснение работает по аналогии и вызывает особую форму мотивации, которую Бэтсон и Шоу определяют как поведение, «вызванное сочувствием к нуждающемуся человеку» (р. 110).

Таким образом, забота Су Ан о благополучии другого человека созвучна с дефиницией Роберта Шаффера (2000) о «действиях, которые приносят пользу другим людям, помогая, поддерживая и поощряя достижение их целей или благополучие». Большая часть исследований просоциального поведения с момента появления этой концепции в 1970-х годах была посвящена моральному развитию детей (Choi et al., 2011; Leahy, 1979; Shaffer, 2000), что перекликается со стратегией, использованной в фильме «Поезд в Пусан»: многие эпизоды, особенно в первой половине фильма, представлены с точки зрения Су Ан. Она изображена в рамках традиции представления о детях как 
о невинных, открытых сердцах и более способных к альтруистическому поведению, чем взрослые, что все еще является распространенной концепцией в Южной Корее. Она разрушает эгоцентричные представления Сок У, когда на короткое и опасное время пассажиры высаживаются на станции Тэджон. Сок У думает, что договорился с другом, и уводит Су Ан от других пассажиров. В последующем обмене мнениями Су Ан критикует эгоизм отца, шокируя его до глубины души, чем инициирует процесс изменений. Услышав о его договоренности, она сразу же хочет включить в нее новых знакомых, которых они завели в поезде, особенно Сон Гён и Сан Хва (43:08):

Су Ан: Я пойду расскажу остальным.

Сок У: Не нужно.

Су Ан: Конечно, нужно.

Сок У: Забудь о них! Мы все сами по себе!

Су Ан: Ты заботишься только о себе. Вот почему мама ушла.

Су Ан проявляет доброту, не ожидая вознаграждения, но зрители согласуют ее действия с вознаграждением - выживанием. Поэтому аффективное удовлетворение вызывает тот факт, что в конце фильма просоциальный, но зараженный Сок У поручает Су Ан заботам Сон Гён, так же как Сан Хва поручил Сон Гён заботам Сок У. Эффект визуально усиливается ближе к финалу, когда Сок У, Су Ан и Сон Гён убегают от преследующей их толпы зомби в поисках безопасности на поезде, приведенном в движение машинистом первого поезда (рис. 2). Сцена погони, в которой зрители сосредоточены на беглецах , рассчитана на создание сильного аффекта, вызванного надеждой и тревогой. Она представляет собой совокупность ракурсов сзади беглецов, фронтальных с низким углом и кадров преследующих зомби с разных ракурсов. Размещение камеры усиливает тревогу за счет таких деталей, как расстояние, которое нужно преодолеть, и огромное количество преследователей (см. рис. 2, верх), в то время как фронтальные кадры с низким углом подчеркивают препятствия беглецов (Сок У несет Су Ан, Сон Гён беременна см. рис. 2, низ). В кадрах, снятых с высоты, все в окружении (здания, поезда, железнодорожные пути, сходящаяся орда зомби) направлено к фокальной точке в верхней части экрана, к затуманенному горизонту, где может быть безопасно. Все в сцене, что движется - поезд, люди и зомби - устремлено к этой точке выхода, которая является символом надежды. Поскольку возможность спасения сохраняется, зрители надеются, что их эмоциональная привязанность не будет напрасной. 

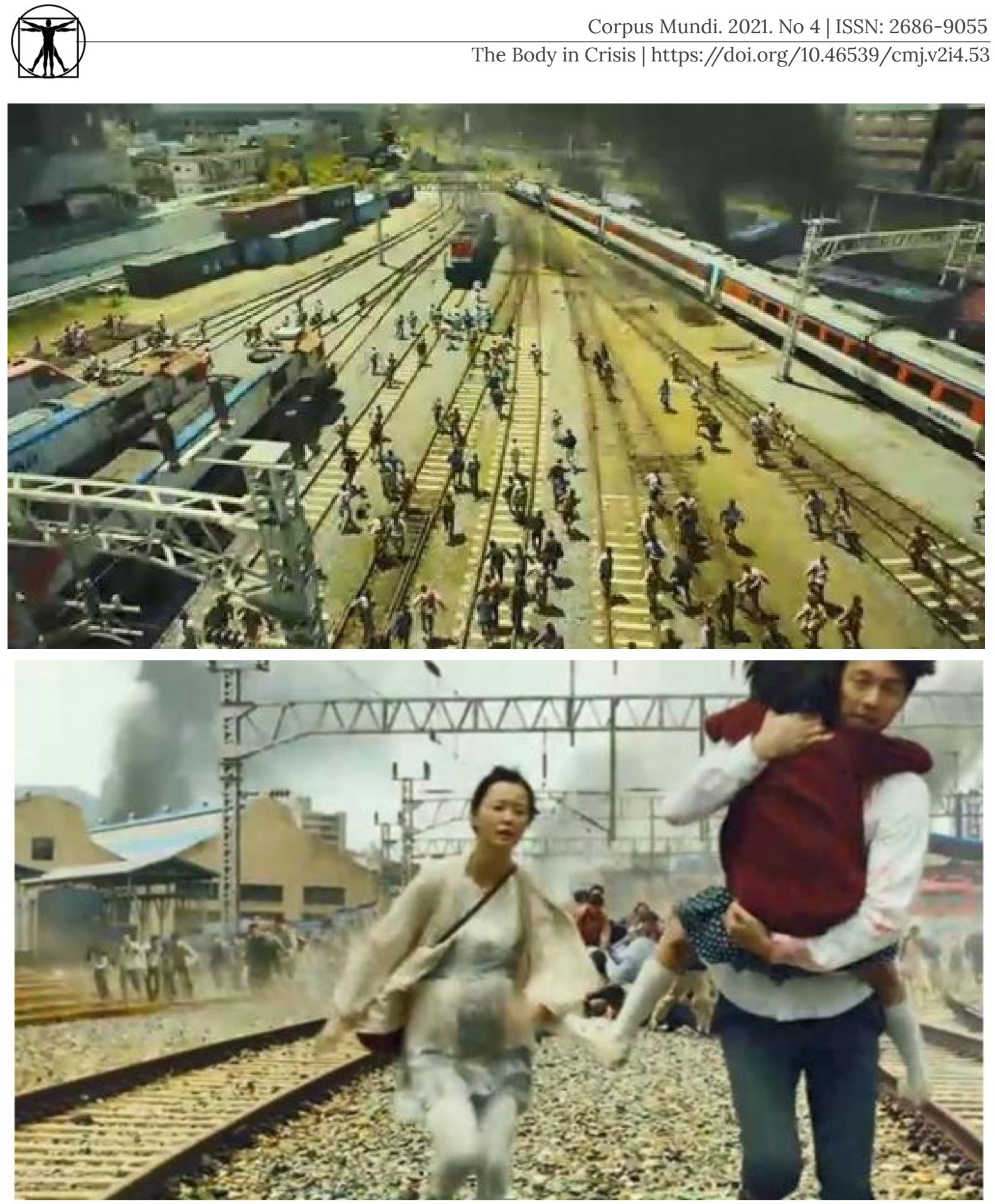

Рисунок 2. Охота зомби в фильме «Поезд в Пусан».

Вверху: вид с воздуха; внизу: низкий ракурс, контрплан.

Figure 2. Zombie pursuit in Train to Busan. Top: Aerial view; Bottom: low angle reverse shot.

Аналогичная двойственность возникает в пяти фронтальных кадрах с низким ракурсом, которые дважды перекликаются с воздушными съемками в последовательности план - контрплан (как на рис. 2). Низкое расположение камеры сужает визуальное расстояние между преследуемыми и преследователями, тем самым усиливая тревогу зрителей. Эти трое персонажей вызывают 
наибольшее сочувствие. Аффективная тревога усиливается еще двумя способами. Во-первых, музыка в саундтреке мелодически и инструментально перекликается с тревожной "Ecstasy of Gold" Эннио Морриконе. Во-вторых, мы наблюдаем возвращение метафоры «Нация - это семья», поскольку три персонажа визуально выглядят как семья, и предполагаемое, но маловероятное романтическое завершение может привести к такому варианту.

Образ слившейся семьи меняет представление о том, что такое нация, поскольку, в отличие от недифференцированной орды зомби, в такой воображаемой семье будет двое детей, каждый из которых имеет кровное родство с одним из родителей и не имеет кровного родства друг $\mathrm{c}$ другом. Нация является многообразной, а не однородной. Разумеется, этого не происходит. После того, как они благополучно садятся в поезд, они сталкиваются с Ён Соком в стадии зомбификации, и в неизбежной борьбе Сок У успевает столкнуть его, однако теперь он тоже заражается. Финал Сок У - единственное исследование зомбификации, предложенное в любом из этих фильмов. Попрощавшись и доверив Су Ан Сон Гён, он направляется к задней части поезда, чтобы успеть выброситься из него до превращения. Находясь там, он возвращается к самому счастливому моменту жизни, вспоминая рождение Су Ан, и особенно остро - как держал ее крошечную ножку между большим и указательным пальцами (см. рис. 3).

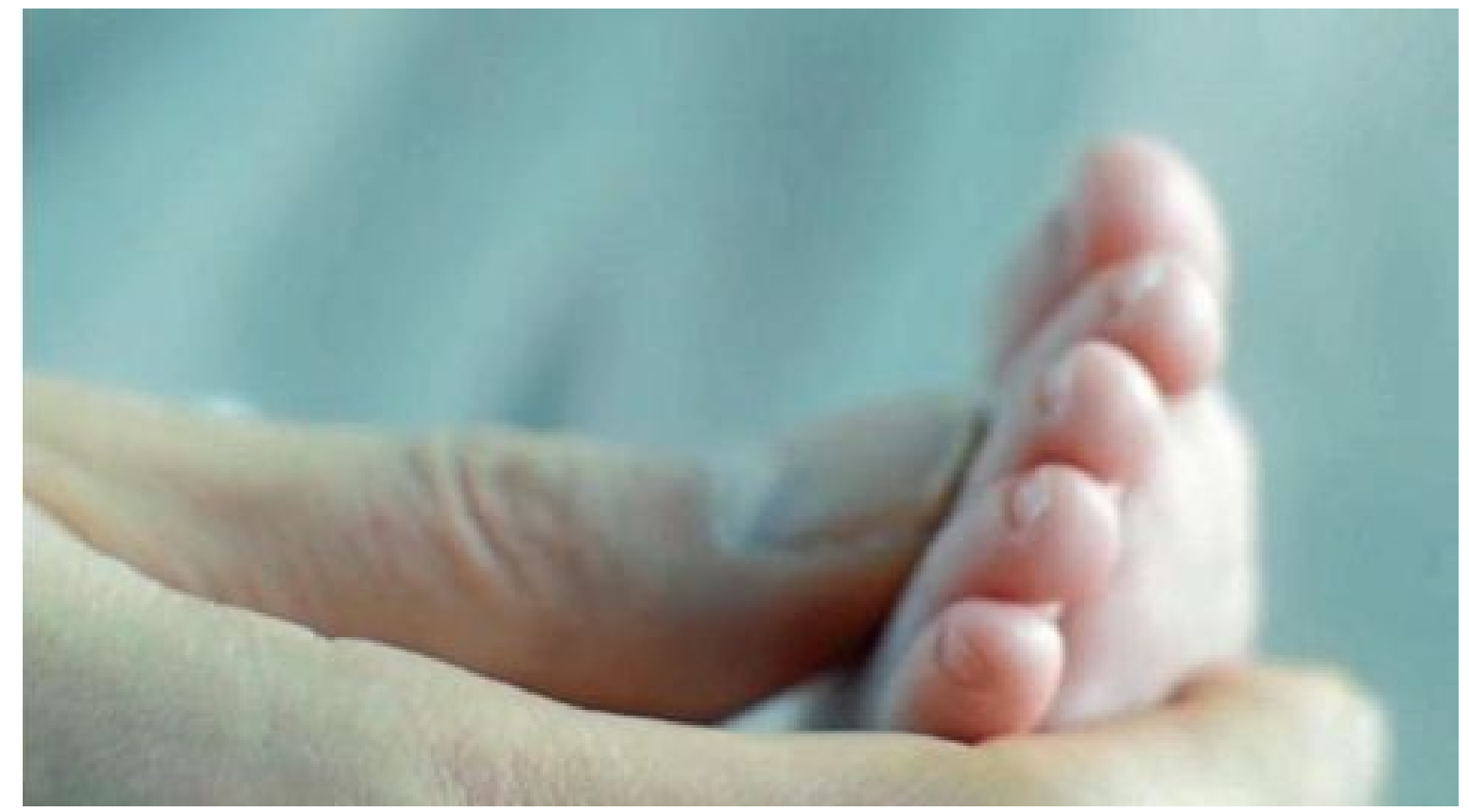

Рисунок 3: Квалиа в воспоминании, фильм «Поезд в Пусан»

Figure 3: Memory of qualia in Train to Busan

Эта сцена показывает элементы сознания, которое теряет человек, превращаясь в зомби: разум, самосознание, память, восприятие, интенцио- 
нальность, эмоции, эмпатию и, как свидетельствует яркое воспоминание о ножке Су Ан, перцептивные квалиа, то есть конкретные отдельные случаи субъективного опыта, или «то, как вещи выглядят, кажутся и предстают перед сознательными наблюдателями» (McLaughlin, p. 856) В начале фильма потеря памяти предвещается размышлениями Сок У, что зомби не помнят, как работает раздвижная дверь, но его последние моменты представляют более тонкий и всеобъемлющий взгляд на то, что значит быть человеком. Его падение из кабины в момент наступления зомбификации обрисовано только в виде тени, как и в «Станции Сеул», но теперь это более явная тень его прежнего «я», символизирующая переход от человечности, которую он открыл в этом путешествии, к нечеловеческому состоянию зомби. Его усилиями были спасены Су Ан и Сон Гён. После прибытия в Пусан они избегают обстрела, когда приближаются к военному заграждению, потому что солдаты слышат, как Су Ан поет песню, которую она научилась петь для своего отца. Это действие определяет ее как человека, но также подтверждает, что человечность должна быть интерсубъективной.

\section{Зомби-апокалипсис и искупительный сценарий главного героя}

Развитие персонажа часто происходит по одинаковым сценариям. В повседневном мире поездка из Сеула в Пусан на поезде КТХ занимает менее трех часов. В фильме путешествие прерывается, сначала из-за неудачной попытки найти охрану на станции Тэджон, а затем из-за блокировки линии на станции Восточный Тэгу. Хотя длительное время поездки не является необходимым условием самопознания и морального искупления Сок У, оно способствует этому процессу практически и тематически. Сок У реализует разновидность сценария искупления, который основан на предположении, что индивиды одновременно социальны и обладают агентностью, так что их субъектность развивается из диалога между социальностью и агентностью. Отказаться от агентности, как это сделал Сок У, работая управляющим фондом, значит стать чем-то мало отличающимся от зомби, в то время как сценарий искупления предполагает, что агентность персонажа позволяет ему изменить ситуацию, в которую он попал, в лучшую сторону (Colvin, p. 221, цит. Maruna). Здесь сценарий искупления включает пять этапов: доказательства того, что персонаж живет предосудительной жизнью; выражение персонажем эгоистических убеждений; реакцию других; конфронтацию, которая побуждает к самоанализу; и последующие изменения в отношении и поведении. Развивая этот сценарий искупления как основную модификацию метафоры «Жизнь это путешествие» и, в частности, как путешествие от эгоизма к просоциальному поведению, «Поезд в Пусан» продолжает тенденцию южнокорейского кино, когда зомби используются как второстепенный элемент по отношению к основной истории о человеческих отношениях. Это вновь показано в фильме 
«Ярость», который синтезирует исторический жанр с зомби-блокбастером и добавляет элементы юмора, современной сатиры.

«Ярость» - это коллаж из мотивов фильмов о зомби: вызывающие зомбофикацию ресурсы, накопленные богатыми и влиятельными людьми; города, где здания разрушены и заброшены, а улицы усеяны телами и мусором; самоотверженные герои. Но самым сильным тематическим элементом является мотив искупления, на котором строится история главного героя, принца Канлима. Прожив десять лет в качестве политического заложника в Цин (Китай), Канлим возвращается в Чосон по приказу своего брата, наследного принца, который участвует в перевороте против своего некомпетентного и параноидального отца и хочет, чтобы Канлим вывез наследную принцессу из страны в безопасное место. Канлим не интересуется политикой или властью и хочет поскорее вернуться к своей гедонистической, развратной жизни в Пекине. Рассказ о борьбе за власть переплетается с повествованием об эпидемии зомби, когда социопатический военный министр Ким устраивает налет на голландское торговое судно, которое продает оружие. На судне находится член команды, превратившийся в зомби. Он кусает одного из солдат Кима. Ким отправляет солдата домой и планирует воспользоваться возникшим хаосом, чтобы захватить власть и объявить себя королем. Как во многих фильмах, представители правительственных институтов оказываются причастными к вспышке зомби-инфекции, а неконтролируемый голод зомби манифестирует жажду власти, которая развращает эти институты. Канлим осуществляет тот же сценарий искупления, который был использован в фильме «Поезд в Пусан», и, преодолевая коварство Кима и нашествие зомби, превращается из праздного гедониста в лидера, который воплощает метафору «Нация - это семья» в своей готовности услышать мольбы народа и стремиться уменьшить человеческие страдания и улучшить социальное благополучие.

\section{Заключение}

Как отмечает Дэниел В. Дрезнер, истории о зомби заканчиваются одним из двух способов: «уничтожением / усмирением всех зомби или истреблением человечества» (2011, р.9). В целом, эти варианты доступны южнокорейскому кино: «Скорая помощь», «Станция Сеул» и «Поезд в Пусан» указывают на второй, трагический вариант, в то время как «Ярость»- это триумфальное героическое повествование. Позднее появление фильмов о зомби в Южной Корее позволило привнести в кино повествовательные формы, атрибуты и контекст, которые предшествуют, например, фильму Дэнни Бойла «28 дней спустя» (2002): зомби быстро перемещаются, а их тяга к потреблению обычно отражает неолиберальные проявления современного капитализма и потенциально разрушительные последствия стремления социальных и экономических элит к власти и краткосрочной финансовой выгоде. Два важных компонента это ярко выраженные просоциальные темы и мотив искупления. Контрасты 
между просоциальным и эгоистичным поведением стали характерной чертой южнокорейского кино и телевизионной драмы примерно с 1990 года, где они были аспектом социальной критики крайней концентрации богатства в руках горстки людей и коррупции в правовой и политической системах, которые поддерживают неравенство и несправедливость и извлекают из них прибыль. Некоторые эпизоды фильма «Ярость» явно намекают на импичмент президента Пак Кын Хе в 2016 году за ряд должностных преступлений. Эта отсылка особенно очевидна в конце фильма, где собравшиеся при свете факелов граждане празднуют победу над зомби и смену режима, что является визуальной цитатой протестов при свечах, которые сыграли важную роль в отстранении президента. Просоциальное поведение и сценарий искупления сходятся в этой точке.

Смешение жанров в «Ярости» показывает движение к поджанру комедийных картин о зомби. Они спорадически появлялись на экранах в 1980-х годах и утвердились в западном кинематографе после фильма «Зомби по имени Шон» (2004). Как объясняет Роджер А. Пейн, комедийные истории о зомби разрушают основы жанра, «создавая персонажей, ситуации и повествования, которые не полностью сосредоточены на апокалиптической природе ситуации» (р. 220). Далее он утверждает, что сатира и черная комедия могут эффективно критиковать эгоцентризм элитарных персонажей и предоставлять альтернативные перспективы (р. 213). Зомби-комедия «Странное семейство: Зомби на продажу», вышедшая в 2019 году, затрагивает темы коррумпированной фармацевтической компании, стоящей за появлением первого зомби, и попытки использовать ситуацию в финансовых целях, но является скорее жанровой мешаниной, чем нарушением традиции, как это было сделано в ее главных предшественниках - американских фильмах «Зомби по имени Шон», «Добро пожаловать в Zомбилэнд» (2009) и «Тепло наших тел» (2013). Для успешной зомби-комедии необходима как съемочная группа, так и аудитория, хорошо знакомая с зомби-традицией, чтобы добиться взаимодействия знакомого и отличающегося, которое будет иметь комический эффект, и на данный момент небольшое количество зомби-фильмов, снятых в Южной Корее, не дает такой возможности.

\section{Список литературы / References}

Bartsch, A., Appel, M., \& Storch, D. (2010). Meta-Emotions at the Movies: The Role of the Need for Affect in Audiences' Experience of Horror and Drama. Communication Research, 37(2), 167-190.

Batson, C. D., \& Shaw, L. L. (1991). Evidence for altruism: Toward a pluralism of prosocial motives. Psychological Inquiry, 2(2), 107-122. doi: 10.1207/s15327965pli0202_1

Benson-Allott, C. (2015). Dreadful architecture: Zones of horror in Alien and Lee Bontecou's Wall Sculptures. Journal of Visual Culture, 14(3), 267-278. doi: 10.1177/1470412915607926 
Bishop, K. W. (2015). How zombies conquered popular culture: The multifarious walking dead in the 21st century. McFarland \& Company, Inc., Publishers.

Blake, L. (2015). 'Are we worth saving? You tell me': neoliberalism, zombies and the failure of free trade. Gothic Studies, 17(2), 26-41. doi: 10.7227/GS.17.2.3

Choi, J., Johnson, D. W., \& Johnson, R. (2011). Relationships among cooperative learning experiences, social interdependence, children's aggression, victimization, and prosocial behaviors: Interdependence, aggression, and prosocial behavior. Journal of Applied Social Psychology, 41(4), 976-1003. doi: 10.1111/j.1559-1816.2011.00744.x

Colvin, S. (2015). Why should Criminology Care about Literary Fiction? Literature, Life Narratives and Telling Untellable Stories. Punishment \& Society, 17(2), 211-229.

Drezner, D. W. (2011). Theory of International Politics and Zombies. Princeton, NJ: Princeton University Press.

Drezner, D. W. (2014). Metaphor of the Living Dead: Or, the Effect of the Zombie Apocalypse on Public Policy. Discourse Social Research: An International Quarterly, 81 (4), 825-849.

Hoglund, J. A. (2013). Parables for the paranoid: Affect and the War Gothic. Continuum, 27(3), 397-407. doi: /10.1080/10304312.2013.772103

Leahy, R. L. (1979). Development of Conceptions of Prosocial Behavior: Information Affecting Rewards Given for Altruism and Kindness. Developmental Psychology, 15(1), 34-37.

Maruna, S. (2001). Making Good: How Ex-Convicts Reform and Rebuild Their Lives. Washington, DC: American Psychological Association.

McLaughlin, B. P. (2016). Hill on Phenomenal Consciousness. Philosophical Studies, 173(3), 851-860.

Miall, D. S. (1989). Beyond the Schema Given: Affective Comprehension of Literary Narratives. Cognition E Emotion, 3(1), 55-78.

Payne, R. A. (2017). Laughing off a zombie apocalypse: The value of comedic and satirical narratives. International Studies Perspectives, 18(2), 211-224. doi: 10.1093/isp/ekv026

Shaffer, D. R. (2000). Social and Personality Development. Belmont, CA: Wadsworth/Thomson Learning.

Tomkins, S. (1963). Affect, Imagery, Consciousness Vol II: The Negative Affects. New York: Springer Publishing.

Travis, M. (2015). We're all infected: Legal personhood, bare life and the walking dead. International Journal for the Semiotics of Law - Revue Internationale de Sémiotique Juridique, 28(4), 787-800. https://doi.org/10.1007/s11196-014-9396-3

Winter, B. (2014). Horror Movies and the Cognitive Ecology of Primary Metaphors. Metaphor and Symbol, 29(3), 151-170. doi: 10.1080/10926488.2014.924280

Wonser, R., \& Boyns, D. (2016). Between the Living and Undead: How Zombie Cinema Reflects the Social Construction of Risk, the Anxious Self, and Disease Pandemic. The Sociological Quarterly, 57(4), 628-653. doi: 10.1111/tsq.12150

\section{Фильмография / Filmography}

28 Days Later. Dir. Danny Boyle. USA: DNA Films, 2002. Film.

"Ambulance" (Aembyuleons) in Horror Stories (Museoun Iyagi). Dir. Kim Gok and Kim Sun. Korea: Lotte Entertainment, 2012 
Dark Forest (Jugeumui Sup). Dir. Kim Jeong-Min. Korea: CJ Entertainment, 2006. Film.

Kingdom (Kingdeom). Dir. Kim Seong-Hun. Korea: AStory, 2019. TV Drama Series.

A Monstrous Corpse (Goesi). Dir. Gang Beom-Gu. Korea: Hanrim Films, 1981. Film.

The Neighbour Zombie (Iutjip Jombi). Dir. O Yeong-Du, Ryu Hun, Hong Yeong-Geun, Jang Yun-Jeong. Korea: Kino Mangosteen, 2010. Film.

The Odd Family: Zombie on Sale (Gimyohan Gajok). Dir. Lee Min-Jae. Korea: Cinezoo, 2019. Film. Rampant (Changgwol). Dir. Kim Seong-Hun. Korea: Leeyang Film, 2018. Film.

Seoul Station (Seoulyeok). Dir. Yeon Sang-Ho. Korea: Studio Dadashow, 2016. Animation.

Shaun of the Dead. Dir. Edgar Wright. USA: StudioCanal, 2004. Film.

Train to Busan (Busanhaeng). Dir. Yeon Sang-Ho. Korea: Next Entertainment World,2016. Film. Warm Bodies. Dir. Jonathan Levine. USA: Mandeville Films, 2013. Film.

Zombieland. Dir. Ruben Fleischer. USA: Relativity Media, 2009. 